Utah State University

DigitalCommons@USU

\title{
Regeneration of aspen following partial and strip understory protection harvest in boreal mixedwood forests
}

\author{
Alison D. Lennie \\ Simon M. Landsausser \\ Victor J. Lieffers \\ Derek Sidders
}

Follow this and additional works at: https://digitalcommons.usu.edu/aspen_bib

Part of the Forest Sciences Commons

\section{Recommended Citation}

Lennie, Alison D.; Landsausser, Simon M.; Lieffers, Victor J.; and Sidders, Derek, "Regeneration of aspen following partial and strip understory protection harvest in boreal mixedwood forests" (2009). Aspen Bibliography. Paper 3478.

https://digitalcommons.usu.edu/aspen_bib/3478

This Article is brought to you for free and open access by the Aspen Research at DigitalCommons@USU. It has been accepted for inclusion in Aspen Bibliography by an authorized administrator of DigitalCommons@USU. For more information, please contact

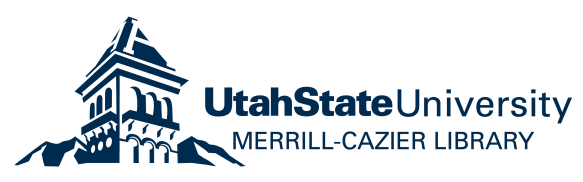




\title{
Regeneration of aspen following partial and strip understory protection harvest in boreal mixedwood forests
}

\author{
by Alison D. Lennie ${ }^{1}$, Simon M. Landhäusser ${ }^{1,2}$, Victor J. Lieffers ${ }^{1}$ and Derek Sidders ${ }^{3}$
}

\begin{abstract}
Trembling aspen regeneration was studied in 2 types of partial harvest systems designed to harvest mature aspen but protect immature spruce and encourage natural aspen regeneration. Two partial harvest systems, where the residual aspen was either left in strips or was dispersed uniformly, were compared to traditional clearcuts. After the first and second year since harvest, aspen sucker density and growth was similar between the 2 partial harvests, but was much lower than in the clearcuts. However, in the partial cuts the regeneration density was very much dependent on the location relative to residual trees. The density of regeneration was inversely related to the basal area of residual aspen; however, sucker height was inversely related to the basal area of the residual spruce. Although there were adequate numbers of suckers after partial harvest, their viability and contribution to the long-term productivity of these mixedwood stands is not clear.
\end{abstract}

Key words: silvicultural systems, forest management, residual canopy, white spruce, Populus tremuloides, Picea glauca, traffic

\section{RÉSUMÉ}

La régénération du peuplier faux-tremble a été étudiée dans le cas de deux modes de coupe partielle conçus pour récolter les trembles à maturité mais pour protéger les épinettes en croissance et favoriser la régénération naturelle du tremble. Deux modes de coupe partielle, où les trembles résiduels ont été retenus dans des bandes ou dispersés uniformément, ont été comparés à des coupes à blanc traditionnelles. Cependant, dans les coupes partielles, la densité de la régénération a été très dépendante de localisation relative aux arbres résiduels. Même si le nombre de drageons est adéquat après une coupe partielle, leur viabilité et leur contribution à long terme à la productivité de ces peuplements mélangés nest pas évidente.

Mots clés : régimes sylvicoles, aménagement forestier, couvert résiduel, épinette blanche, Populus tremuloides, Picea glauca, trafic

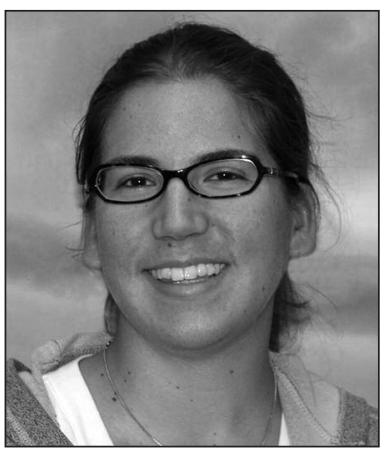

Alison D. Lennie

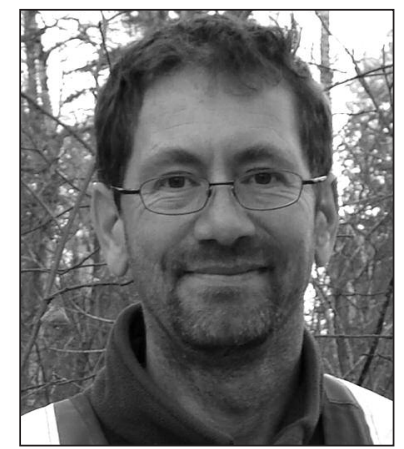

Simon M. Landhäusser

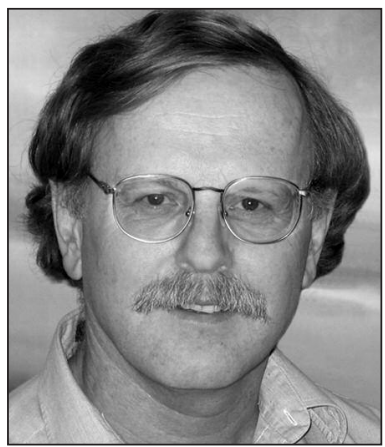

Victor J. Lieffers

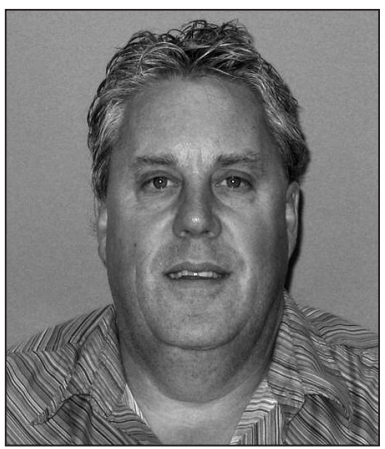

Derek Sidders

\section{Introduction}

A large portion of Canada's boreal forest is dominated by mixed-species stands of trembling aspen (Populus tremuloides Michx.) and white spruce (Picea glauca (Moench) Voss). Following disturbance, these mixedwood forests rapidly redevelop an overstory of aspen while the slower-growing and longer-lived white spruce establishes under the aspen (Peterson and Peterson 1992, Lieffers et al. 1996b, Brais et al. 2004).

At about 60 years, the aspen is mature and ready for harvest. At this time, however, the spruce is still in the understory and unmerchantable (Lieffers et al 1996a). Brace and Bella (1988) developed a 2-pass "understory protection" system to harvest the mature aspen while leaving the understory spruce to grow for another 40 to 60 years. Generally, these protection systems left some residual mature aspen trees on these sites to minimize windthrow of the understory spruce (Navratil et al. 1994).

\footnotetext{
${ }^{1}$ Centre for Enhanced Forest Management, Department of Renewable Resources, University of Alberta, 4-42 Earth Sciences Building, Edmonton, Alberta T6G 2E3.

${ }^{2}$ Corresponding author. E-mail: Simon.Landhausser@ualberta.ca

${ }^{3}$ Canadian Forestry Service, Northern Forestry Centre, 5320 - 122 St. Edmonton, Alberta T6H 3S5.
} 
After logging mature aspen, a site is never fully stocked with spruce because all trees are removed from the machine corridors to allow logging equipment access into the stand, and secondly, there are areas in the stands that have low densities or no spruce due to the spatial variability of natural regeneration of white spruce. For this reason, it is desirable to have aspen regeneration fill in these understocked spaces following understory protection harvesting in mixedwood stands. Aspen regeneration, however, may not grow well in these understory protection sites since aspen is a shade-intolerant species and it is generally understood that optimal regeneration is achieved by clearcutting (Navratil 1991). In addition, there is a growing body of evidence that density of aspen regeneration is suppressed by low densities of residual aspen trees (Schier et al. 1985, Huffman et al. 1999, Palik et al. 2003, Man et al. 2008). However, this study of aspen regeneration following understory protection offers some differences to these previous studies on aspen regeneration following partial-cut logging. The very regular pattern of machine corridors interspersed with protected areas offers an opportunity to study aspen regeneration in regards to the spatial arrangement of residual trees. As ramets of aspen clones can remain connected throughout the life of the clone (DesRochers and Lieffers 2001) root systems of cut stumps can have suckering suppressed by the auxins produced by the residual living trees. We propose that this suppression will be stronger if the residual aspen trees are evenly dispersed than when residual trees are concentrated in strips far away from the cut stems of aspen.

Finally, the layout of this experiment also allowed us to determine the influence of traffic on the regeneration of aspen on the machine corridors as distal parts of the corridors (away from the landing) had only a small fraction of the machine traffic relative to areas closer to the landings. Machine traffic is known to influence suckering (Bates et al. 1993, Zenner et al. 2007, Mundell et al. 2008), especially if logging is done in summer months.

In this study we examined the natural regeneration and growth of aspen root suckers as a result of 2 different patterns of understory protection harvesting; one retained the residual aspen in concentrated buffers while the other had the residual aspen evenly dispersed. These 2 cutting patterns were selected as promising options from a range of cutting patterns tested for protection of understory spruce from windthrow (MacIsaac et al. 1999). Aspen regeneration density and growth were compared between these 2 harvesting systems and compared to clearcut systems at the stand scale. We also assessed the aspen regeneration at the microsite scale, i.e., machine corridors, different distances from residual aspen, and zones of high and low amounts of machine traffic.

\section{Materials and Methods \\ Site description}

The study was conducted in 5 areas across the Boreal Mixedwood natural sub-region of Alberta: WNW High Level, WSW of High Level, Grande Prairie, Wandering River and Conklin, Alberta, Canada. At each area, 2 stands (20 to 50 hectares in size) of trembling aspen-dominated forest with an understory of white spruce were selected. All stands were aspen-dominated mixedwoods with understories of blueberry (Vaccinium myrtilloides), green alder (Alnus crispa), Canada buffalo-berry (Shepherdia canadensis) and prickly rose (Rosa acicularis) (Beckingham and Archibald 1996). The aspen was about $24 \mathrm{~m}$ tall, had an average of $24 \mathrm{~cm}$ diameter at breast height, and a basal area of about $29 \mathrm{~m}^{2} \cdot \mathrm{ha}^{-1}$.

Stands were harvested in the winter of 2005/2006. During that winter, there was little snow accumulation $(<20 \mathrm{~cm}$; Environment Canada n.d.), resulting in frozen soils in all areas harvested. Each of the ten stands was divided into 4 cutting treatments (5 ha to 10 ha each): clearcut (CC), an uncut control, and 2 types of understory-protection harvests, a concentrated wind buffer (CWB) and a distributed wind buffer (DWB) (Fig. 1 and Fig. 2). Full-tree harvesting was conducted using tracked feller-bunchers. Trees were selected for harvest based on residual tree distribution, rather than size. All harvested trees were bunched on the machine corridors and moved by grapple skidders equipped with tire chains to landings outside the harvest area.

In these treatments, equipment used for harvesting and skidding was restricted to the machine corridors and landings. Machine corridors were oriented north-south, perpendicular to prevailing winds from the west. Machine corridors ranged in length from $100 \mathrm{~m}$ to $250 \mathrm{~m}$, and were restricted to

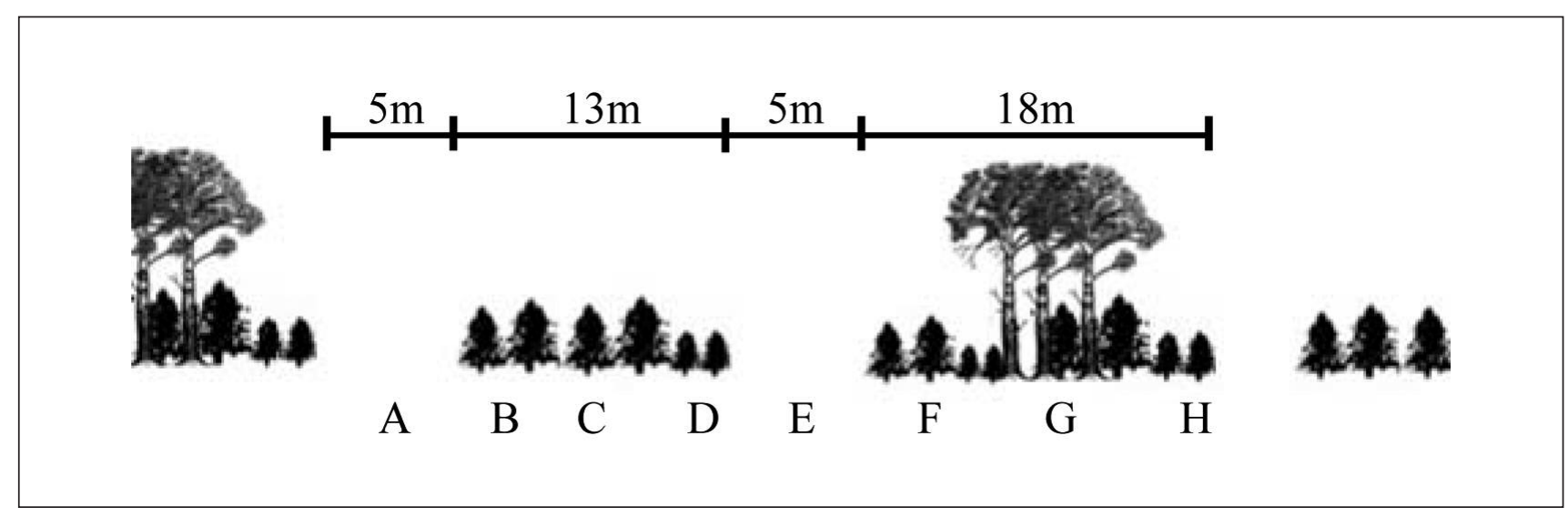

Fig. 1. Layout of the concentrated wind buffer (CWB) harvest treatment. The harvest treatment consisted of alternating 13-m-wide spruce retention strips and 18-m-wide spruce retention strips with a central 5-m-wide canopy retention strip; retention strips were separated by 5 -m-wide machine corridors. Transects to measure regeneration consisted of 8 microsite locations $(A-H)$ perpendicular to the harvesting pattern. 


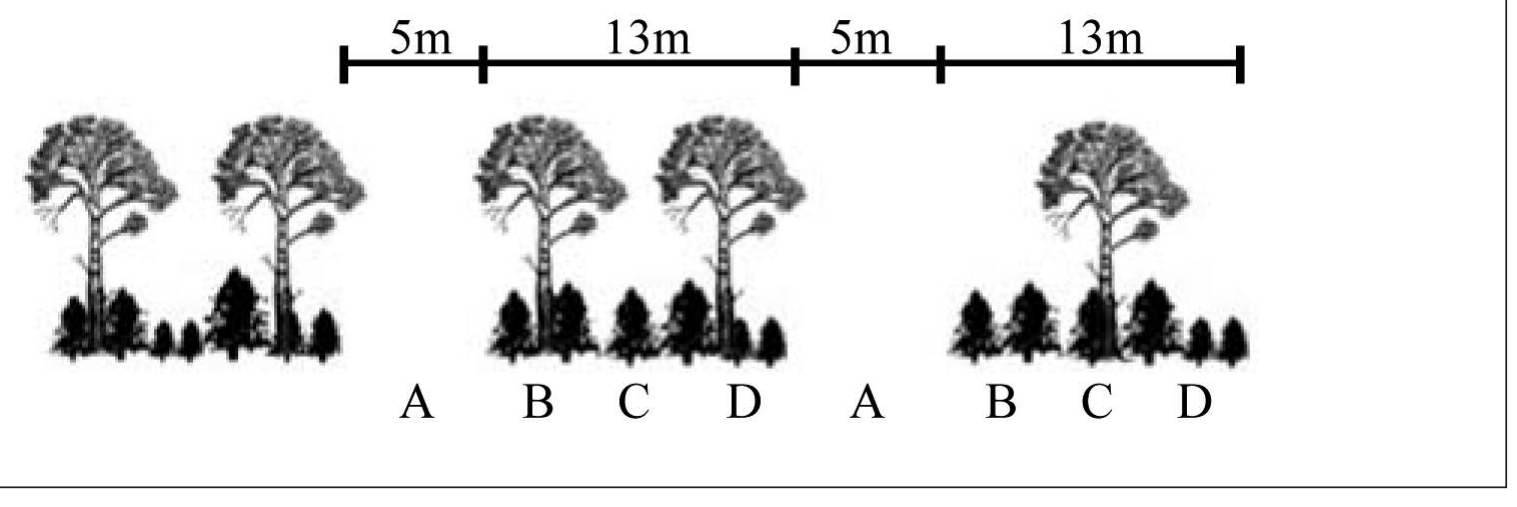

Fig. 2. Layout of the distributed wind buffer (DWB) harvest treatment. Harvest treatment design consisted of 13-m-wide spruce retention strips, separated by 5-m-wide machine corridors. Regeneration was measured along transects consisting of 4 microsite locations (A-D) perpendicular to the harvesting pattern.

$5 \mathrm{~m}$ in width. Throughout harvesting, efforts were made to protect understory white spruce adjacent to the machine corridors; the reach of the feller buncher was $6.5 \mathrm{~m}$ from the corridor edge.

After cutting, the CWB treatment had alternating 13-mand 18-m-wide strips of understory spruce, separated by 5 $\mathrm{m}$-wide machine corridors (Fig. 1). In the 13-m-wide retention strip, all of the overstory aspen was removed, but in the 18 -m-wide retention strip there was a 5-m-wide central strip of uncut aspen.

In the DWB treatment 13-m-wide retention strips alternated with 5-m-wide machine corridors (Fig. 2). Here retained mature canopy trees were uniformly dispersed over this 13-m-wide strip. Belt-transects (description see below) indicated that the CWB retained 23\% of the canopy aspen and the DWB 30\%.

In the clearcut treatment (CC) all canopy and understory trees were harvested and removed using conventional clearcut techniques with random skidding. Only 8 of the 10 stands had a clearcut treatment and 2 clearcut sites were removed from the study after the first growing season because these sites were mistakenly site prepared and planted to spruce.

\section{Measurements}

Stand assessments were conducted in the summer/fall of 2005, prior to harvesting and again in 2006 after the harvest was completed (Keddy and Sidders 2007). Five-metre-wide belt transects were run across the stands in an east-west direction, perpendicular to the machine corridors. Transects were divided into $20-\mathrm{m}$ lengths $\left(100 \mathrm{~m}^{2}\right)$, and all trees within were surveyed for density, basal area, canopy position, and diameter at breast height. Both the CWB and DWB had a similar average density and basal area of understory spruce. The CWB had $4.7 \mathrm{~m}^{2} \cdot \mathrm{ha}^{-1}$ or 375 stems per ha retained while the DWB had $5.3 \mathrm{~m}^{2} \cdot \mathrm{ha}^{-1}$ or 374 stems per ha of understory spruce retained for release. The understory spruce ranged from about $5 \mathrm{~m}$ to $12 \mathrm{~m}$ in height.

In August 2006, aspen sucker density was tallied in $10-\mathrm{m}^{2}$ circular plots positioned on the same 5-m-wide belt transects as described above. In the CWB treatment, 3 transects (each
$41 \mathrm{~m}$ long) containing 8 microsite positions were established on each site, perpendicular to the machine corridors and retention strips and aspen regeneration was sampled. In the DWB, 6 transects (18 m long) were established at each site with 4 different microsite positions. Plots were placed on various microsite positions in the CWB and DWB harvests (Fig. 1 and Fig. 2). In the CWB microsite plots were located on positions: (A) machine corridor; (B) near edge of 13-mwide retention strip; $(C)$ centre of $13-m$-wide retention strip; (D) far edge of 13-m-wide retention strip; (E) second machine corridor; $(\mathrm{F})$ near edge of 18 -m-wide retention strip; (G) centre of $18 \mathrm{~m}$-wide-retention strip (under 5-m-wide $100 \%$ forest retention); and $(\mathrm{H})$ far edge of 18 -m-wide retention strip (Fig. 1). In the DWB microsite plots were located on: (A) mid-machine corridor; (B) near edge of 13-m-wide retention strip; $(\mathrm{C})$ centre of 13-m-wide retention strip; and (D) far edge of retention strip (Fig. 2). In clearcuts, aspen regeneration was assessed using transects $(36 \mathrm{~m})$ with 6 evenly spaced regeneration plots at each site.

Each circular regeneration plot was divided into quarters to tally aspen suckers and measure the height of the tallest sucker. In August of 2007, the regeneration was re-measured to include suckers initiated in both 2006 and 2007 and the tallest sucker was measured in each quarter of the plot.

Soil temperature was also assessed in the different microsite positions within each of the 2 harvest treatments, clearcut, and in the unharvested control stands. The CWB had data loggers deployed in positions C, E, F, and G; the DWB in positions A and C. Both the clearcut and unharvested control had a single data logger deployed under representative conditions for each harvest treatment. In total, there were 6 replicates of temperature transects in the CWB, DWB and unharvested control and 3 replicates in clearcuts. Temperature sensors (HOBO 8, Onset Computer Corporation, Bourne, MA) were vacuum-packed and positioned at a soil depth of $12 \mathrm{~cm}$ from the top of the LFH layer, to collect growing-season soil temperatures. Hourly data were recorded for the duration of the growing season (June 8 to September 15, 2006) and mean-daily soil temperature and growing degree day (GDD) values above $8^{\circ} \mathrm{C}$ were calculated for the growing season in each of the replicates. 
To assess the impact of traffic on the machine corridors, aspen regeneration was measured at 3 positions along machine corridors of the CWB treatment on all 10 sites. Measurements were taken at the distal end of the machine corridor ( 0 to 6 passes with the skidder), in the middle ( 8 to 20 skidder passes) and near the logging deck (more than 20 skidder passes). Pairs of $10-\mathrm{m}^{2}$ regeneration plots were surveyed at each position. Three root pits $(40 \times 40 \times 12 \mathrm{~cm}$ deep) were dug at each position perpendicular to the corridor and root damage was assessed on the aspen roots that were between $0.5 \mathrm{~cm}$ and $2 \mathrm{~cm}$ in diameter; damage was categorized as scuffing - only the bark and phloem damaged, crushing - bark, phloem, and xylem damaged, and breakage - roots totally severed and expressed as number of wounds per length of root.

\section{Data analysis}

The 5 main site locations were considered to be experimental blocks, each of which contained 2 replicates of the harvest treatments (randomized complete block design with replication). Transects within each site and treatment were treated as subsamples and averaged for each site and treatment combination. The data for stem density were transformed with natural logarithms to meet assumptions of normality and homoscedasticity for ANOVA. To test for differences in microsites on aspen regeneration, microsites in both the DWB and CWB datasets were analysed separately.

All above data were analysed using Mixed Models in SAS (SAS Institute, Cary, NC). The Tukey-Kramer test at a significance level of $\alpha=0.05$ was used for all post-hoc comparisons among treatment means. We also examined the relationships between density and height of sucker regeneration with the basal area of post-harvest deciduous or coniferous trees. This was done by linking the data collected from the circular regeneration plots, averaged across all sample points, to the data from the belt transects that were collected pre- and postharvest in the same cutting unit. Aspen regeneration density and height was regressed against the post-harvest variables for 2006 and 2007, using simple and multiple regression techniques; however, no multiple regression calculations approached significant values and as a result data were analysed using simple regression analyses.

\section{Results}

Impact of harvest design on aspen regeneration

In the first summer after harvest, aspen sucker density was twice as high in the clearcuts (74026 stems per hectare [sph]), compared to the concentrated wind buffer (CWB) with $38535 \mathrm{sph}$ and the distributed wind buffer (DWB) with $30750 \mathrm{sph}(\mathrm{p}<0.001)$ (Fig. 3A). Overall, sucker densities were not different between the 2 partial harvest types. After the second growing season sucker numbers in the clearcut treatment were still higher with an average of $50513 \mathrm{sph}$ compared to 35033 and $30250 \mathrm{sph}$ for the CWB and DWB treatment, respectively $(\mathrm{p}=0.005)$.

In the first summer, suckers in the clearcut were also taller $(97 \mathrm{~cm})$ than those in the CWB $(77 \mathrm{~cm})$ and DWB $(70 \mathrm{~cm})$ $(\mathrm{p}=0.001)$ (Fig. 3B). Similarly, in the second summer, suckers in the clearcut were tallest $(156 \mathrm{~cm})$ but only significantly so between the clearcut and the DWB with $125 \mathrm{~cm}$ $(\mathrm{p}=0.033)$ (Fig. 3B).

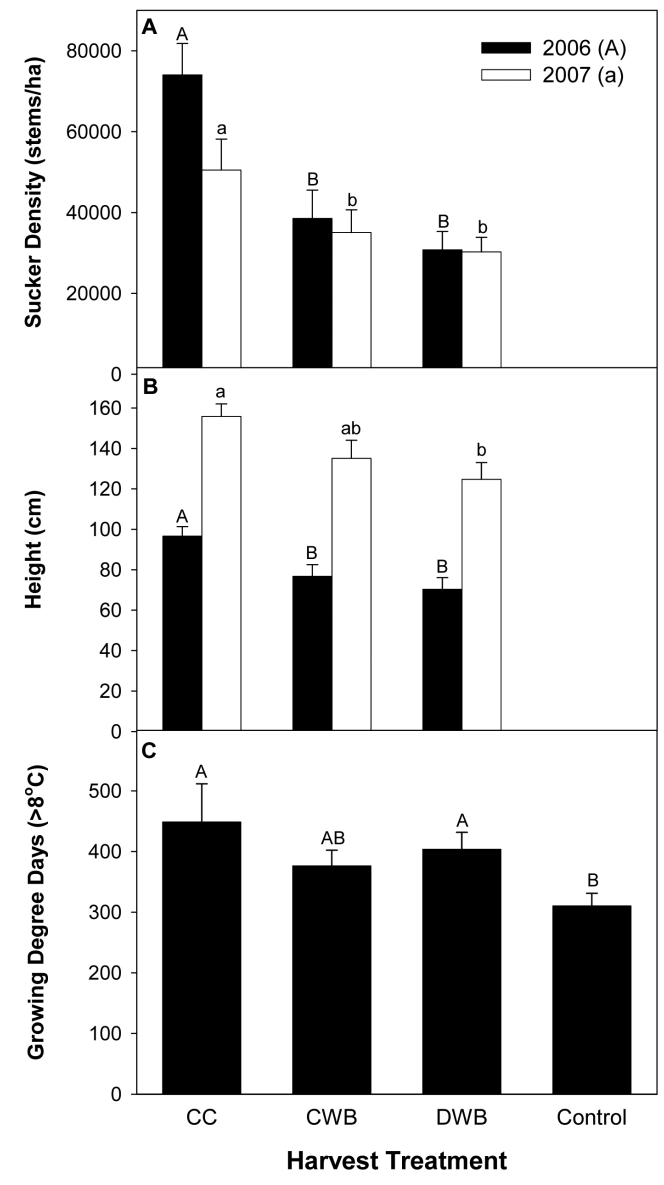

Fig. 3. Aspen sucker density (A), sucker height (B) in 2006 and 2007, and soil temperature growing degree days (GDD) over $8^{\circ} \mathrm{C}(\mathrm{C})$ in 2006, in response to harvest pattern: clearcut (CC), concentrated wind buffer (CWB), distributed wind buffer (DWB) harvest and control. Data from 2006 and 2007 were analyzed separately and bars with different letters were significantly different at $\alpha=0.05$. Error bars represent the standard error of the mean, $n=10$ for CWB and DWB, $n=8$ for CC in 2006 and $n=$ 6 for CC in 2007 for aspen density and height and $n=6$ for CWB, DWB and Control and $n=3$ for CC for GDD.

The accumulation of soil temperature growing degree days (GDD, above $8^{\circ} \mathrm{C}$ ) was influenced by harvest treatment $(\mathrm{p}=0.04)$ (Fig 3C); GDD was highest in clearcuts (449), followed by DWB (404) and CWB (376) and was lowest in the unharvested control (310).

\section{Impact of microsite position on aspen regeneration}

After the first growing season, sucker densities in the CWB were highest on the machine corridors (positions $\mathrm{A}$ and $\mathrm{E}$; $61600 \mathrm{sph}$ ) (Fig. 4A) compared to all other positions $(\mathrm{p}<0.001)$. The lowest aspen sucker densities were found under the strips of residual aspen (position G; $18150 \mathrm{sph}$ ) and on the positions next to the residual strips (position $\mathrm{F}$ and $\mathrm{H}$; $30299 \mathrm{sph}$ ). Positions with only residual spruce (B, C, and D) had intermediate sucker densities of $35444 \mathrm{sph}$. Similar 


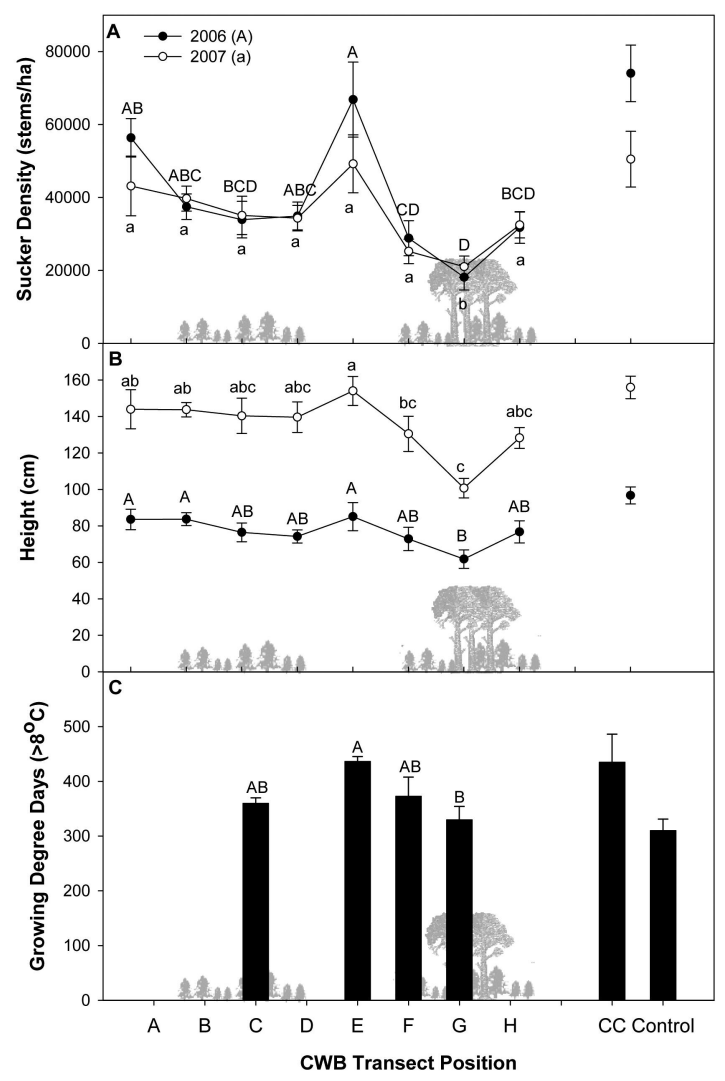

Fig. 4. Average $( \pm S E)$ of aspen sucker density $(A)$; sucker height (B) (both 2006 and 2007 measurements [ $=10$ ]); and soil temperature growing degree days (GDD) over $8^{\circ} \mathrm{C}$ in 2006 ( $\mathrm{n}=$ 6) (C) for selected microsite positions in the concentrated wind buffer (CWB) treatment. Clearcut harvest and uncut control (only for GDD) averages are shown for comparison. Years were analysed separately and bars with different letters are significantly different at $\alpha=0.05$ for each treatment.

trends in aspen sucker densities in relation to position were also found for the second growing season $(\mathrm{p}=0.05)$, but as a result of the mortality between the first and second growing season, especially on the machine corridors, these betweenposition differences were smaller (Fig 4A).

In the first growing season (2006), microsite position affected the height of suckers in the CWB $(\mathrm{p}<0.001)$. However, the only significant difference in height was between suckers establishing under the retained strip of aspen (position G) $(62 \mathrm{~cm})$ and suckers found on machine corridors (positions $\mathrm{E}$ and $\mathrm{A}$ ) and at the edge of the 13-m-wide spruce retention strip (position B) furthest away from the aspen retention strip; at this distal position height was $84 \mathrm{~cm}$ (Fig. 4B). After the second growing season (2007), these differences became more pronounced, where the average height of suckers under the residual aspen strip $(101 \mathrm{~cm})$ were shorter than suckers growing in all other microsite positions $(140 \mathrm{~cm}$ across all positions; $\mathrm{p}<0.001$; Fig 4B).

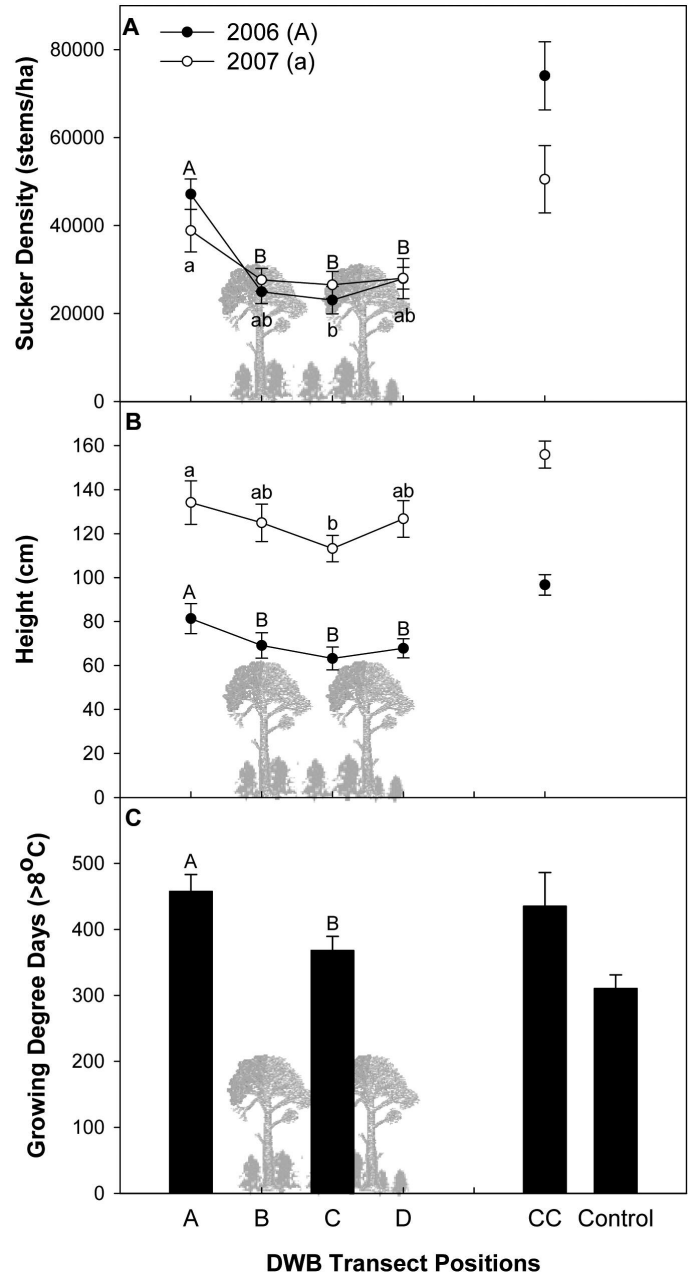

Fig. 5. Average $( \pm S E)$ of aspen sucker density (A); sucker height (B) (both 2006 and 2007 measurements; $n=10$ ); and soil temperature growing degree days (GDD) over $8^{\circ} \mathrm{C}$ (only 2006; $n=$ 6) (C) for selected microsite positions in the concentrated wind buffer (CWB) treatment. Clearcut harvest and control (only GDD) treatment averages are shown for comparison. Years were analyzed separately and bars with different letters are significantly different at $\alpha=0.05$ for each treatment.

Soil temperature GDD were influenced by microsite location in the CWB $(\mathrm{p}=0.016)$. The highest soil temperature GDD were found on the machine corridor (position E) with 437 GDD while the lowest was found in the middle of the retention strips (position G) with 330 GDD (Fig. 4C).

After the first growing season, sucker densities in the DWB harvest treatment were highest on the machine corridors (position A) with 47117 sph compared to the 3 other positions on the retention strips, with an average of 25294 sph ( $\mathrm{p}<0.001$; Fig 5A). After the second growing season, the machine corridor position had still higher density of suckers (38 $833 \mathrm{sph}$ ) but the difference was now significant only between the machine corridor and the centre of the $13-\mathrm{m}$ wide retention strip with $26516 \mathrm{sph}$ (position $\mathrm{C} ; \mathrm{p}=0.032$ ). 


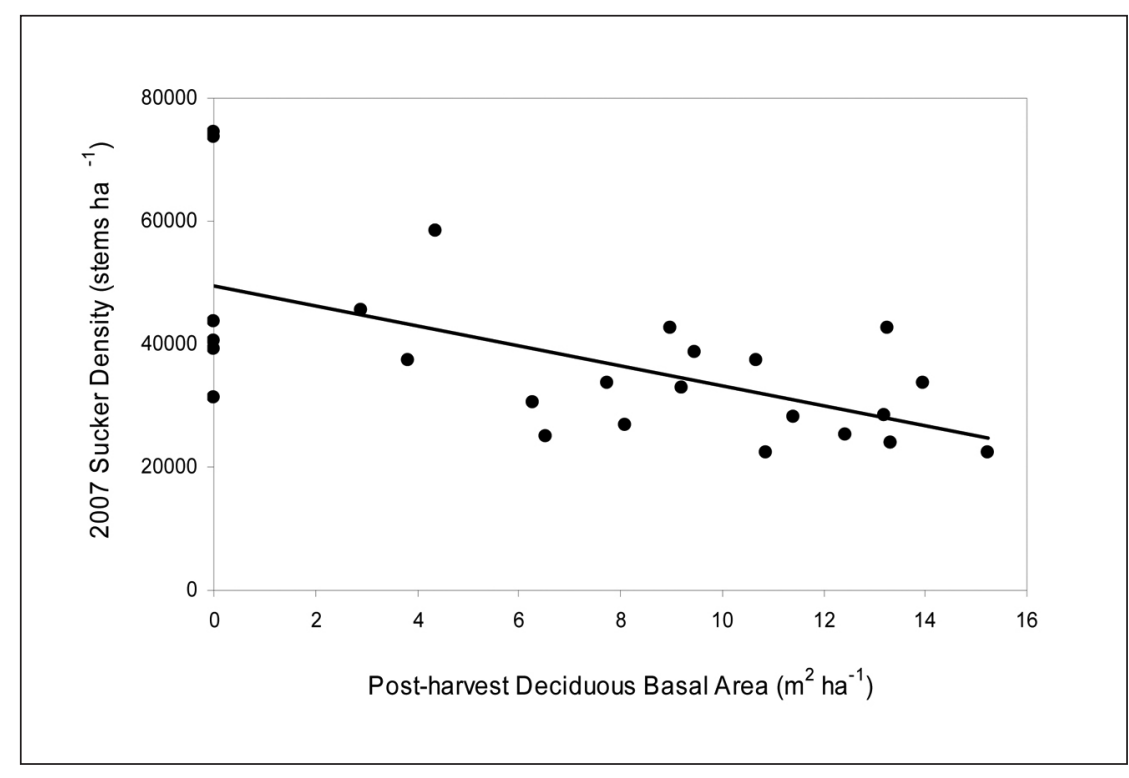

Fig. 6. Relationship between aspen sucker density after the second growing season and basal area of residual deciduous trees post harvest at the stand level and across all treatments ( $y=-1622.35 x+49359 ; R^{2}=0.37 ; n=27$ ).

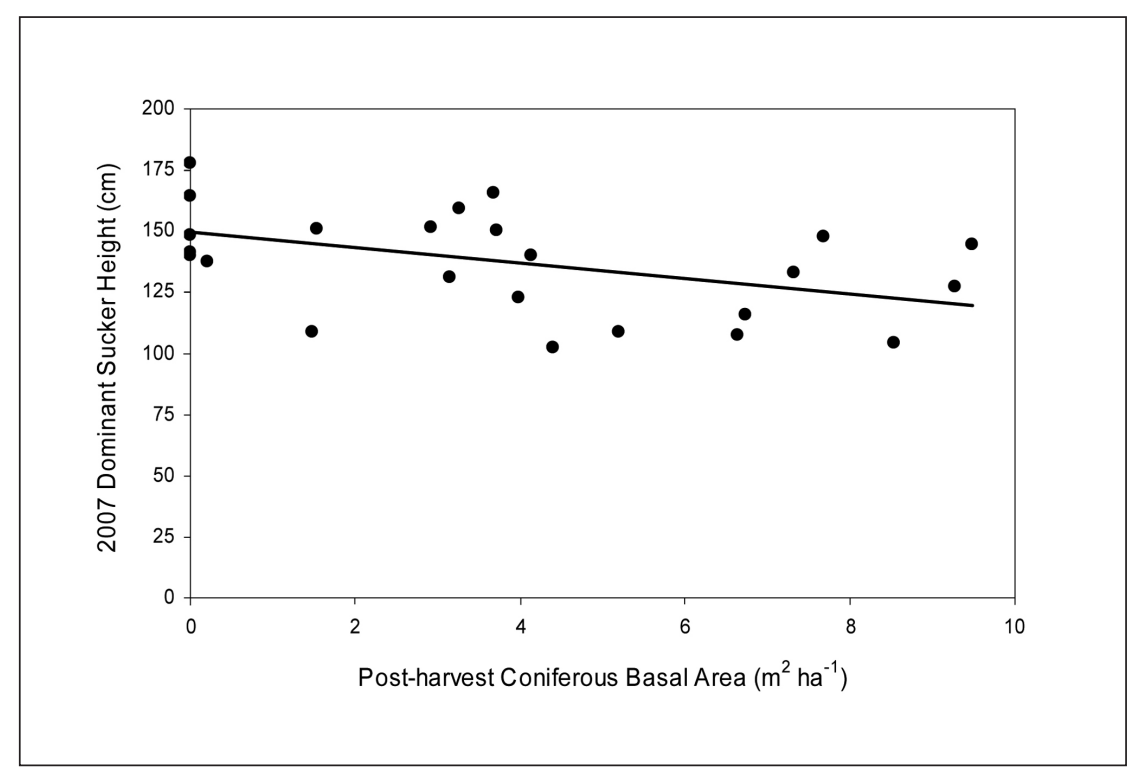

Fig. 7. Height of dominant aspen suckers after the second growing season since harvest, in relation to residual coniferous basal area $\left(y=-3.17 x+149.6 ; R^{2}=0.23 ; n=27\right.$ ).

Impact of post-harvest stand composition on sucker regeneration

The residual post-harvest deciduous overstory had a strong negative impact on sucker density in year $1\left(\mathrm{R}^{2}=0.54\right.$; $\mathrm{p}$ $<0.001)$ and year $2\left(\mathrm{R}^{2}=0.37 ; \mathrm{p}=0.001\right)$ while post-harvest conifer basal area did not. Sucker density decreased with increasing basal area of retained deciduous trees (Fig. 6). On the other hand, aspen sucker height was only affected by post-harvest conifer basal area. Aspen height decreased with increasing basal area of the post-harvest-protected conifers after the first $\left(\mathrm{R}^{2}=0.41 ; \mathrm{p}<\right.$ $0.001)$ and second growing season $\left(\mathrm{R}^{2}=\right.$ 0.22 ; $\mathrm{p}=0.017$; Fig. 7 ).

Impact of traffic on root wounding and aspen regeneration

In this study there was no difference in the amount of aspen-root wounding on the machine corridors as a result of increased traffic, but overall there were more $(\mathrm{p}=0.004)$ and larger wounds $(\mathrm{p}=$ 0.043 ) in roots on machine corridors than in roots of the untrafficked control areas. Sucker regeneration density $(\mathrm{p}=$ $0.107)$ and sucker height $(p=0.290)$, after the second growing season, were not different in relation to the amount of traffic along the machine corridor.

\section{Discussion}

There was little difference in the density of aspen regeneration between the distributed and the concentrated wind buffer treatments (DWB and CWB; Fig. 3 ). Therefore, the configuration of the residual aspen in the 2 partial cut regimes did not significantly affect the overall performance of aspen suckers at the larger scale of this study. Since the residual trees in the DWB treatment were spread uniformly over the treatment area, we had expected that soil temperatures and suckering in these areas would be the lowest because of the closer proximity to residual trees providing increased shade and hormonal suppres-

In 2006, suckers on the machine corridors were taller $(81$ $\mathrm{cm})$ than suckers on the other 3 transect positions $(\mathrm{p}<0.001)$. Suckers on the retention strip edge (positions B and D) were $69 \mathrm{~cm}$ tall, whereas suckers in the mid position (C) were 63 $\mathrm{cm}$ tall (Fig 5B). After the second growing season, the suckers on the machine corridors were still tallest $(134 \mathrm{~cm})$, but were only significantly taller than those in the middle of the retention strip ( $\mathrm{p}=0.029$; Fig. $5 \mathrm{~B})$.

In 2006, soil growing degree days above $8^{\circ} \mathrm{C}(\mathrm{GDD})$ on the machine corridors (position A) were 458 GDD compared to 368 GDD in the centre of the 13-m-wide retention strip (position $\mathrm{C} ; \mathrm{p}=0.019$; Fig. 5C). sion of suckering (Steneker 1974, Frey et al. 2003). The reasons for similar regeneration densities are not clear, small clone sizes and/or uniform shading from the relative tall $(5 \mathrm{~m}$ to $12 \mathrm{~m}$ ) protected understory spruce could have similarly affected the aspen regeneration density at the stand scale for both treatments. The slightly lower sucker numbers in the DWB were likely more related to the slightly higher levels of canopy retention in this treatment $30 \%$ retention in the DWB vs. $23 \%$ in the CWB). A similar response was also observed for height growth of the suckers in the first 2 years.

It appears that residual spruce had a greater effect on sucker height growth (Fig. 7) and sucker density was more 
affected by the amount of residual aspen (Fig. 6). The overall suppression of suckering by a residual canopy of aspen and retained basal area of understory spruce supports the findings that aspen regeneration is best after clearcutting and is suppressed by leaving residuals on the site (Huffman et al. 1999, Palik et al. 2003, Brais et al. 2004, Man et al. 2008).

There were, however, significant differences in aspen regeneration at the various microsite positions within each treatment. Machine corridors always produced the highest sucker densities and tallest suckers while positions under the strip of retained aspen produced the lowest densities and shortest suckers. It is likely that at that scale, proximity to residual trees (aspen and understory spruce) suppressed aspen sucker regeneration and growth through apical dominance (Steneker 1974), shading (Huffman et al. 1999, Brais et al. 2004), reduced soil temperature as measured in GDD (Fraser et al. 2002, Brais et al 2004, Landhäusser et al. 2006) and increased competition for other resources (Canham et al. 2004) influenced sucker regeneration and growth (Frey et al 2003).

The fact that the aspen regeneration density and height on the machine corridors was not affected by the number of skidder passes likely relates to the frozen soils at the time of logging. There likely had been deep frost penetration into the ground at the time of logging because of the small amount of snow in early winter; thus the weight of the logging machines was supported by frozen soil, resulting in only moderate damage to the roots. While moderate damage can promote sucker regeneration (Fraser et al. 2004), heavy machine traffic on unfrozen soil could have had detrimental effects on suckering and sucker performance (Zenner et al. 2007, Mundell et al. 2008).

Although there were relatively high numbers of suckers across most microsites and harvest treatments 2 growing seasons after harvest, it is not clear which of these suckers will be viable and contribute to the long-term productivity of these stands. The fact that the suckers in the areas with spruce and aspen retention had slower growth rates than on the corridors and clearcut sites, suggests that there could be problems with performance of these aspen saplings and trees as time goes on. Messier et al. (1999) suggested that shade-intolerant tree species establishing in a light-limited environment may establish and grow reasonably well for a few years but if their growth rates drop below a critical level, they are likely to die. In addition, these weakened aspen saplings are more likely to be attacked by insects or diseases than open-grown aspen, which could further increase the mortality rates (Houston 1992, Mallett 1992). The competition from the already 5-m- to $12 \mathrm{~m}$-tall residual conifers will also increase over time as the conifers grow in size and leaf area density. We speculate that in areas of the stands where the density of understory spruce is high most of the aspen regeneration will die, while in open areas with very few understory spruce the aspen will be more successful-filling in the empty spaces. However, longer-term studies are needed to assess the fate of the aspen regeneration in understory spruce protection systems over time.

\section{Acknowledgements}

We thank Eckehart Marenholz; Jessica Snedden, Cosmin Man, Derek Bakker, Melanie Mattila, Ian Curran, Kevin Renkema, Geoff Kershaw, Jill Fraser, Jennifer Langhorst, Isabelle Turcotte, and Tyana Rudolfsen for their assistance in the field. Funding was provided by the Mixedwood Manage- ment Association, the Forest Resource Improvement Association of Alberta and NSERC. Alberta Pacific Forest Products, Ainsworth Lumber Co. Weyerhaeuser Co, Footner Forest Products and Tolko Forest Products provided assistance with the harvest of the plots.

\section{References}

Beckingham, J.D. and J.H. Archibald. 1996. Field Guide to Ecosites of Northern Alberta. Natural Resources Canada, Canadian Forest Service, Northwest Region, Northern Forestry Centre, Edmonton, AB. Special Report 5.

Brace, L.G. and I.E. Bella. 1988. Understanding the understory: dilemma or opportunity. In J.K. Samoil (ed.). Management and utilization of northern mixedwoods. pp. 69-98. Can. For. Serv., Edmonton, AB. Info Rep. NOR-X-296.

Bates, P.C., C.R. Blinn and A.A. Alm. 1993. Harvesting impacts on quaking aspen regeneration in northern Minnesota. Can. J. For. Res. 23: 2403-2412.

Brais, S., B.D. Harvey, Y. Bergeron, C. Messier, D. Greene, A. Belleau and D. Paré. 2004. Testing forest ecosystem management in boreal mixedwoods of northwestern Quebec: initial response of aspen stands to different levels of harvesting. Can. J. For. Res. 34: 431-446.

Canham C.D., P.T. LePage and K.D. Coates. 2004. A neighbourhood analysis of canopy tree competition: effects of shading versus crowding. Can. J. For. Res. 34: 778-787.

DesRochers, A. and V.J. Lieffers. 2001. The coarse-root system of mature Populus tremuloides in declining stands in Alberta, Canada. J. Veg. Sci. 12: 355-360.

Environment Canada. n.d. National Climate Data and Information Archive 2005-2006. Available at http://www.climate.weatheroffice.ec. gc.ca/climateData/monthlydata_e.htm [Accessed 29 January, 2009]. Fraser, E., V.J. Lieffers and S.M. Landhäusser. 2004. Wounding of aspen roots promotes suckering. Can. J. Bot. 82: 310-315.

Fraser, E.C., V.J. Lieffers, S.M. Landhäusser and B.R. Frey. 2002. Soil nutrition and temperature as drivers of root suckering in trembling aspen. Can. J. For. Res. 32: 1685-1691.

Frey, B. R., V.J. Lieffers, S.M. Landhäusser, P.G. Comeau and K.J. Greenway. 2003. An analysis of sucker regeneration of trembling aspen. Can. J. For. Res. 33: 1169-1179.

Houston, D.R. 1992. A host-stress-saprogen model for forest dieback-decline diseases. In P.D. Manion and D. Lachance (eds.). Forest decline concepts. pp. 3-25. American Phytopathological Society, St. Paul, MN.

Huffman, R.D., M.A. Fajvan and P.B. Wood. 1999. Effects of residual overstory on aspen development in Minnesota. Can. J. For. Res. 29: 284-289.

Keddy, T. and D. Sidders. 2007. Establishment Report: Understory protection and release, and overstory fibre recovery. From FRIAA OF03-NARCAN-01 Adaptive management of mixedwoods to maximize fibre recovery and retained stem volume growth and ecosystem sustainability. p. 142. Canadian Wood Fibre Centre, Canadian Forest Service, Edmonton, AB.

Landhäusser, S.M., V.J. Lieffers and T. Mulak. 2006. Effects of soil temperature and time of decapitation on sucker initiation of intact Populus tremuloides root systems. Scand. J. For. Res. 21: 299-305.

Lieffers, V.J., R.B. Macmillan, D. MacPherson, K. Branter and J.D. Stewart. 1996a. Semi-natural and intensive silviculture systems for the boreal mixedwood forest. For. Chron. 72: 286-292.

Lieffers, V.J., K.J. Stadt and S. Navratil. 1996b. Age structure and growth of understory white spruce under aspen. Can. J. For. Res. 26: 1002-1007.

MacIsaac, D.A., S. Lux, D. Sidders, and I. Edwards. 1999. Hotchkiss river mixedwood timber harvesting study. For. Chron. 75: 435-438.

Mallett, K.I. 1992. Armillaria root rot in the Canadian prairie provinces. For. Can., North. For. Cent., Edmonton, AB. Inf. Rep. NOR-X-329. 
Man, R., G.J. Kayahara, J.A. Rice and G.B. MacDonald. 2008. Eleven-year responses of a boreal mixedwood stand to partial harvesting; light vegetation and regeneration dynamics. For. Ecol. Manage. 255: 697-706.

Messier, C., R. Doucet, J.-C. Ruel, Y. Claveau, C. Kelly and M.J. Lechowicz. 1999. Functional ecology of advance regeneration in relation to light in boreal forests. Can. J. For. Res. 29: 812-823.

Mundell, T.L., S.M. Landhäusser and V.J. Lieffers. 2008. Root carbohydrates and aspen regeneration in relation to season of harvest and machine traffic. For. Ecol. Manage. 255: 68-74.

Navratil, S. 1991. Regeneration challenges. In S. Navratil and P.B. Chapman (eds.). Aspen management for the 21st century. pp. 15-27. Symposium Proceedings, Can. For. Serv., North. For. Centre and Poplar Coun. Canada, Edmonton, AB.

Navratil, S., L.G. Brace, E.A. Sauder and S. Lux. 1994. Silvicultural and harvesting options to favor immature white spruce and aspen regeneration in boreal mixedwoods. Can. For. Serv., North. For. Centre, Inf. Rep. NOR-X-327
Palik, B., K. Cease, L. Egeland and C. Blinn. 2003. Aspen regeneration in riparian management zones in northern Minnesota: effects of residual overstory and harvest method. N. J. Appl. For. 20: 79-84. Peterson, E.B. and N.M. Peterson. 1992. Ecology, management, and use of aspen and balsam poplar in the prairie provinces. Can. For. Serv., North. For. Centre. Special Report 1.

Schier, G.A., J.R. Jones and R.P. Winokur. 1985. Vegetative regeneration. In N.V DeByle and R.P. Winokur (eds.). Aspen: ecology and management in the western United States. pp. 29-33. USDA For. Serv., Fort Collins, CO. GTR RM-119.

Steneker, G.A. 1974. Factors affecting the suckering of trembling aspen. For. Chron. 50: 32-34.

Zenner, E.K., J.T. Fauksee, A.L. Berger and K.J. Puettmann. 2007. Impacts of skidding traffic intensity on soil disturbance, soil recovery, and aspen regeneration in north central Minnesota. North. J. Appl. For. 24:177-183. 